\title{
Investigation of Enteric Viruses in the Feces of Neotropical Migratory Birds Captured on the Coast of the State of Pará, Brazil
}

\section{-Author(s)}

Guerreiro AN'
Moraes CCG'
Marinho ANR"
Barros BCV"
Bezerra DAM"
Bandeira RS'
Silva RR ${ }^{\prime \prime \prime}$
Rocha DCC"
Meneses AMCIV
Luz MA
Paz GS
Mascarenhas JDP"I

Laboratório de Zoonoses, Faculdade de Medicina Veterinária, Universidade Federal do Pará, Campus Castanhal, Rodovia BR316 Km 62 s/n, Saudade, Castanhal, PA 68740-970, Brazil

" Instituto Evandro Chagas (IEC), BR-316 Km 7 s/n, Distrito de Levilândia, Ananindeua, PA 67030-000, Brazil.

III Laboratório Nacional de Agricultura (Lanagro/PA), Ministério da Agricultura, Pecuária e Abastecimento (MAPA), Av. Almirante Barroso1234, Distrito de Marco, Belém, PA 66093-032, Brazil.

Iv Universidade Federal Rural da Amazônia (UFRA), Av. Presidente Tancredo Neves 2501, Belém, PA 66077-530.

$\checkmark$ Universidade Estadual Paulista (UNESP), Distrito de Rubião Jr. S/N, Botucatu, SP 18618-681.

\section{Mail Address}

Corresponding author e-mail address Joana D'Arc Pereira Mascarenhas Instituto Evandro Chagas (IEC), Rodovia BR-316 Km 7 s/n, Distrito de Levilândia, Seção de Virologia, Ananindeua - PA, 67030-000 - Brazil

Tel: $\quad$ (+55) 9132142016

Email: joanamascarenhas@iec.pa.gov.br

\section{- Keywords}

Animals, Amazônia, picobirnavirus, reovirus, rotavirus, RT-PCR.

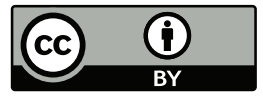

Submitted: 16/July/2017

Approved: 30/October/2017

\section{ABSTRACT}

Migratory birds can become long-distance vectors for a wide range of microorganisms and can cause human disease, being the Brazilian coast a gateway for northern migratory birds. These animals are considered natural reservoirs of different viruses that cause important diseases, being relevant research of viral pathogens in migratory birds to epidemiology surveillance. The objective of the study was to investigate the presence of avian rotavirus (AvRV), avian reovirus (ARV) and picobirnavirus (PBV) in Neotropical migratory birds captured on the coast of Brazil. A total of 23 individual fecal samples of the migratory birds species Calidris pusilla (20 birds), Numenius phaeopus (1 bird) and Charadrius semipalmatus (2 birds) were collected. Fecal suspensions were prepared from the collected samples for subsequent extraction of double-stranded RNA (dsRNA), which was subjected to polyacrylamide gel electrophoresis (PAGE) and reverse transcription polymerase chain reaction (RT-PCR). The electrophoretic profiles were not detected by PAGE, and the amplification for the studied viruses PBV, ARV and AvRV (specie D, gene VP6 and NSP4) were negative. Positivity for AvRVD, VP7 gene was of $4.35 \%$ (1/23) for the migratory bird Calidris pusilla. After sequencing and building the tree of phylogenetic relationships avian Rotavirus Group D identified in this study was phylogenetically related and grouped into one branch, together to previously reported AvRVD from Brazil in chicken flocks with $99.8 \%$ nucleotide and 100\% amino acid similarities.

\section{INTRODUCTION}

There are huge numbers of wild animals distributed throughout the world and the diversity of wildlife species is immense. Infectious pathogens that originate in wild animals have become important throughout the world, as they have had substantial impacts on human health, agricultural production, wildlife-based economies and wildlife conservation (Bengis et al., 2004). Wild birds and especially migratory species can become long-distance vectors for a wide range of microorganisms and can cause human disease (Tsiodras et al., 2008). The Brazilian coast is a gateway for northern migratory birds, and there are records of migratory birds extending from the coastal Amazon to the northeastern region of the country. These birds generally arrive in the country from August to October and return to their breeding areas from March to May (Nunes et al., 2006).

The areas where northern migratory birds concentrate are important in the context of epidemiological surveillance of the countries that are included in migratory routes because these animals are considered natural reservoirs of different viruses that cause important diseases, such as avian influenza, Newcastle disease and West Nile virus. These 
Guerreiro AN, Moraes CCG,

Marinho ANR, Barros BCV, Bezerra DAM,

Bandeira RS, Silva RR, Rocha DCC,

Meneses AMC, Luz MA, Paz GS,

Mascarenhas JDP
Investigation of Enteric Viruses in the Feces of Neotropical Migratory Birds Captured on the Coast of the State of Pará, Brazil diseases are of major concern to public authorities and populations (Bengis et al., 2004; Estes \& Greenberg, 2013).

The avian rotaviruses (AvRV) belong to the family Reoviridae, genus Rotavirus, and have a genome consisting of 11 segments of non-enveloped, icosahedral, double-stranded RNA with viral genome that encodes six structural proteins (VP1-VP4, VP6 and VP7) and six non-structural proteins (NSP1-NSP6) (Estes \& Greenberg, 2013). As based on the serological reactivity and genetic variability of VP6 gene, there are at least nine different groups/species, named RVA-RVI and more recently, rotavirus $J$ was proposed as tenth specie (Matthijnssens et al., 2012; Mihalov-Kovács et al., 2015). Birds can be infected by species $A, D, F$ and G (Johne et al., 2011; Otto et al., 2012).

The first report of rotavirus infection in birds was described by Bergeland et al. (1977) in the United States from the intestinal contents of some 2 to 3 week old turkeys with watery diarrhea and high mortality. In Brazil, AvRV was first reported by Alfieri et al. (1989) from diarrheic broiler chickens. Bezerra et al. (2012) analyzed pools of fecal samples from farms distributed among municipalities of the Metropolitan Mesoregion of Belém and detected rotavirus group $D$ by polyacrylamide gel electrophoresis (PAGE) and reverse transcription PCR (RT-PCR). However, there are no data of the occurrence of AvRV in literature on the occurrence of these viruses in migratory birds.

The avian picobirnavirus isolate (PBV) belongs to the family Picobirnaviridae, genus Picobirnavirus with two species: Human picobirnavirus (type species) and Rabbit picobirnavirus (designated species) (Malik et al., 2016). In Brazil, this agent was first described in the intestinal contents of wild black-footed pigmy rice rats (Oryzomys nigripes) and later identified during an outbreak of gastroenteritis involving humans in Brazil (Pereira et al., 1988). In birds, the first report of infection was described in the same year by Alfieri et al. (1988) in broilers. Worldwide the PBV has a wide host range and has been detected in both domestic and captive animals, however, in migratory birds there are no reports on the circulation of this virus.

The avian reovirus (ARV) belongs to the genus Orthoreovirus, subfamily Spinareovirinae, family Reoviridae, and it is a non-enveloped, icosahedral, dsRNA virus. The first isolate in birds was described by Fahey \& Crawley (Goldenberg et al., 2010) and was initially associated with chronic respiratory disease in broilers. In Brazil, evidence of avian reovirus circulation was first reported after the detection of neutralizing antibodies against the virus in free ranged chicken (Dos Santos et al., 2008).

Due to the limited knowledge of the migratory routes of birds in the coastal region of Brazil and noting the importance of these viral agents in the epidemiology of Gallus gallus domesticus, the present study aimed to determine the presence of AvRV, ARV and PBV in Neotropical migratory since there are no data in literature on the occurrence of these viruses in this birds.

\section{MATERIALS AND METHODS}

\section{Clinical Specimens}

Twenty-three fecal samples were collected from migratory birds captured on Corvina Beach (S 00036.648'/ W 047022.860'), Pará, Brazil. Twentyone samples belonged to the order Charadriiformes, family Scolopacidae, with 20 samples from the species Calidris pusilla, one sample from Numenius phaeopus and two samples belonged to the order Ciconiiformes, family Charadriidae from the species Charadrius semipalmatus.

Calidris pusilla is distributed from the west to northern Alaska to northern Canada. During the winter, it is present on the Pacific coast of Mexico to the south of Peru; on the Atlantic coast of the Yucatan Peninsula and the West Indies and also in the coast of Argentina. These birds live in high and low Arctic and subarctic tundra in the wet, often near natural pools, rivers, lakes, river deltas and also dry areas and sandy scrubland along the rivers.

The birds were captured using mist nets with the aid of aluminum rods after ebb tides in locations with food availability. Feces were collected of the cloacae with the aid of a plastic spoon or individually in cardboard boxes lined with aluminum foil and stored in 1.5 $\mathrm{mL}$ Eppendorf tubes and stored in a freezer. After feces collection, the birds were properly identified by ornithologists and biologists showing any clinical signs of diarrhea and released back into the wild.

\section{Sample preparation}

A $1 \mathrm{~mL}$ volume of $10 \%$ phosphate buffered saline (PBS pH 7.0) and $160 \mu \mathrm{L}$ of chloroform were added to each fecal sample. The samples were then stirred for 20 minutes and centrifuged at 3,000 rpm for 10 minutes at $4^{\circ} \mathrm{C}$. The supernatant was carefully collected and stored in a plastic vial at $-20^{\circ} \mathrm{C}$. The viral genome was extracted from the fecal suspensions using guanidine isothiocyanate/silica powder glass according to the 
Guerreiro AN, Moraes CCG, Marinho ANR, Barros BCV, Bezerra DAM, Bandeira RS, Silva RR, Rocha DCC, Meneses AMC, Luz MA, Paz GS, Mascarenhas JDP
Investigation of Enteric Viruses in the Feces of Neotropical Migratory Birds Captured on the Coast of the State of Pará, Brazil method described by Boom et al. (1990) and subjected to PAGE according to Pereira et al. (1993).

\section{RT-PCR}

The AvRVD (Avian Rotavirus D) was screened by RTPCR using the RD6F/RD6R primers for amplification of VP6 gene according to the method of Bezerra et al. (2012). Additionally, a pair of primers were designed to AvRVD VP7 gene RDVP7-F (5' GGA GTG ACG CAC CTG TAT G 3') and RDVP7-R (5' TAG CGT TTG TTG ATT CAA TG $3^{\prime}$ ).

For AvRV belonging to group A the primers Seg10c-s and Seg10-c-as were used according to Trojnar et al. (2009) and the primers Rotvp6-f and Rotvp6-r were used according to Ursu et al. (2011) for the NSP4 and VP6 genes, respectively.

For detection of PBVs (genogroup I), the primers PicoB25(+) and PicoB43(-) were used according to Rosen et al. (2000) to amplify the RdRp gene. For amplification of the ARV S2 gene, the primers PAF and PAR were used according to Zhang et al. (2006).

To obtain complementary DNA (CDNA), the total reaction volume was $25 \mu \mathrm{l}$, and this included $3 \mu \mathrm{L}$ of extracted dsRNA, $1 \mu \mathrm{L}$ of each primer pair $20 \mathrm{mM}$, 16.5 $\mu \mathrm{L}$ of RNase- and DNase-free $\mathrm{H}_{2} \mathrm{O}, 2.5 \mu \mathrm{L}$ of $10 \mathrm{x}$ First-strand buffer (Invitrogen ${ }^{\circledR}$, Life Technologies, Carlsbad, CA, USA), $1 \mu \mathrm{L}$ of deoxynucleotide triphosphates (dNTPs $-10 \mathrm{mM}$, Invitrogen ${ }^{\circledR}$ ), $0.75 \mu \mathrm{L}$ of $\mathrm{MgCl}_{2}\left(50 \mathrm{mM}\right.$, Invitrogen $\left.{ }^{\circledR}\right)$ and $0.25 \mu \mathrm{L}$ of reverse transcriptase (Enzyme Super Script II; 20 U, Invitrogen ${ }^{\circledR}$ ), for 1 hour at $42^{\circ} \mathrm{C}$. The products (CDNA) were then subjected to PCR amplification with final volume of 50 $\mu \mathrm{L}$, with the addition $25 \mu \mathrm{L} c D N A, 18.5 \mu \mathrm{L}$ of RNaseand DNase-free $\mathrm{H} 2 \mathrm{O}, 2.5 \mu \mathrm{L}$ of 10x First-strand buffer (Invitrogen $\left.{ }^{\circledR}\right), 3 \mu \mathrm{L}$ of $\mathrm{dNTPs}\left(10 \mathrm{mM}\right.$, Invitrogen $\left.{ }^{\circledR}\right)$, $0.75 \mu \mathrm{L}$ of $\mathrm{MgCl} 2\left(50 \mathrm{mM}\right.$, Invitrogen $\left.{ }^{\circledR}\right)$ and $0.25 \mu \mathrm{L}$ of Taq DNA Polymerase $\left(2.5 \mathrm{U} / \mu \mathrm{L}\right.$, Invitrogen $\left.{ }^{\circledR}\right)$.

The cycling conditions for amplification of the AvRVD VP6 gene were as follows: $93^{\circ} \mathrm{C}$ for 3 minutes, followed by 35 cycles at $93^{\circ} \mathrm{C}, 55^{\circ} \mathrm{C}$ and $72^{\circ} \mathrm{C}$ for 1 minute each, with a final cycle at $68^{\circ} \mathrm{C}$ for 7 minutes to amplify a 742 bp fragment. For amplification of the AvRVA NSP4 gene, the following cycling conditions were used: $93^{\circ} \mathrm{C}$ for 3 minutes, followed by 35 cycles at $94^{\circ} \mathrm{C}$ and $50^{\circ} \mathrm{C}$ for 1 minute each and $72^{\circ} \mathrm{C}$ for 2 minutes, ending with one cycle at $68^{\circ} \mathrm{C}$ for 7 minutes to obtain a $645 \mathrm{bp}$ fragment and AvRVD VP7 were used: $94^{\circ} \mathrm{C}$ for 2 minutes, followed by 35 cycles at $94^{\circ} \mathrm{C}, 55^{\circ} \mathrm{C}$ and $72^{\circ} \mathrm{C}$ for 1 minute each, with a final cycle at $72^{\circ} \mathrm{C}$ for 5 minutes to amplify a $595 \mathrm{bp}$ fragment. Amplification of the AvRVA VP6 gene was conducted at $95^{\circ} \mathrm{C}$ for 3 minutes, followed by 40 cycles at $95^{\circ} \mathrm{C}$ and $50^{\circ} \mathrm{C}$ for 30 seconds each and $72^{\circ} \mathrm{C}$ for 45 seconds, ending with one cycle at $68^{\circ} \mathrm{C}$ for 7 minutes to obtain a $550 \mathrm{bp}$ fragment.

The positive control used in RT-PCR to AVRVD VP6 and VP7 genes was a field isolate RVD/Chicken-wt/27/ PA/BRA/2008/ (Acess number Genebank: JQ065735; KC669408) and for negative control ultra pure DNAse/ RNAse free water was used.

For amplification of the PBV RdRp gene, the following cycling conditions were used: $94^{\circ} \mathrm{C}$ for 5 minutes, followed by 35 cycles at $94^{\circ} \mathrm{C}$ for 45 seconds, $45^{\circ} \mathrm{C}$ for 30 seconds and $72^{\circ} \mathrm{C}$ for 1 minute, with a final step at $72^{\circ} \mathrm{C}$ for 10 minutes to amplify a $201 \mathrm{bp}$ fragment. The cycling conditions for amplification of the ARV S2 gene were as follows: $93^{\circ} \mathrm{C}$ for 3 minutes, followed by 35 cycles at $93^{\circ} \mathrm{C}, 53^{\circ} \mathrm{C}$ and $72^{\circ} \mathrm{C}$ for 1 minute each, with a final step at $68^{\circ} \mathrm{C}$ for 7 minutes to amplify a 625 bp fragment.

A total of $10 \mu \mathrm{L}$ of the amplified products were separated on a $1.5 \%$ agarose gel with $2 \mu \mathrm{L}$ of bromophenol blue and $2 \mu \mathrm{L}$ of molecular weight marker (123 bp, Invitrogen ${ }^{\circledR}$ ) diluted in $10 \mu \mathrm{L}$ of $1 \mathrm{X}$ Tris/Borate/EDTA (TBE). The gel was then subjected to horizontal electrophoresis for 60 minutes with a mean voltage and amperage of $120 \mathrm{~V}$ and $400 \mathrm{~mA}$, respectively. The bands were observed with the GEL DOC 1000 instrument (Bio-Rad Laboratories, Hercules, (A, USA).

\section{Nucleotide sequencing and phylogenetic analysis}

The positive samples were sequenced in the $A B I$ Prism 3500 genetic analyzer (Applied Biosystems, Foster city, CA, USA) using ABI PRISM ${ }^{\mathrm{TM}}$ Big Dye Terminator Cycle Sequencing (Applied Biosystems, USA) and the same PCR primers with each reaction were repeated for three times to forward and reverse.

After ordering the sequences multiple alignments, using BioEdit software package version 7.2.5 (Hall, 1999) and MEGA V.6.0 programs (Tamura et al., 2013) were edited to build the tree phylogenetic relationships for comparison with rotavirus sequences of reference viruses to groups $A, D, F$ and $G$ available in the databases, using the neighbor joining method with Kimura 2-parameter correction (Kimura, 1980) and bootstrap analysis (2,000 replicates). The analysis of rotaviruses in Neotropical migratory birds characterized in the present study were all made with rotaviruses detected in chicken flocks of the four species that infect avian (AvRVA, AvRVD, AvRVF and AvRVG) due the lack of data about rotaviruses in Neotropical migratory birds. 
Guerreiro AN, Moraes CCG,

Marinho ANR, Barros BCV, Bezerra DAM,

Bandeira RS, Silva RR, Rocha DCC,

Meneses AMC, Luz MA, Paz GS,

Mascarenhas JDP
Investigation of Enteric Viruses in the Feces of Neotropical Migratory Birds Captured on the Coast of the State of Pará, Brazil

\section{GenBank accession numbers}

The sequence data for the VP7 gene from the present study were submitted to the GenBank database with the accession number KX774462.

For the phylogenetic analyzes the following sequences were used:

- RVD/chicken-wt/BRA/94/2010 (KJ101576.1),

- RVD/chicken-wt/BRA/91/PA/2010 (KC669411.1),

- RVD/chicken-wt/BRA/98/2010 (KJ101578.1),

- RVD/chicken-wt/BRA/29/2008 (KJ101568.1),

- RVD/chicken-wt/BRA/40/2009 (KJ101573.1),

- RVD/chicken-wt/BRA/37/PA/2009 (KC669409.1),

- RVD/chicken-wt/BRA/ 105 A/PA/2010 (KC669412.1),

- RVD/chicken-wt/BRA/96/2010 (KJ101577.1),

- RVD/chicken-wt/BRA/43/PA/2009 (KC669414.1),

- RVD/chicken-wt/BRA/69/PA/2010 (KC669410.1),

- RVD/chicken-wt/BRA/36/2009 (KJ101571.1),

- RVD/chicken-wt/BRA/109/PA/2011 (KC669413.1),

- RVD/chicken-wt/DEU/05V0049/2005 GU733451.1),

- RVD/chiken-wt/KOR/D62/2013 (KM254196.1),

- RVD/chicken/IND/UKD48/2012 (KF142489.1),

- RVA/pheasant-tc/GER/10V0112H5/2010/ G23P[37] (JX204816.1),

- RVA/chicken-wt/BRA/USPARV06/2009 (KC962123.1),

- RVA/chicken-wt/KOR/AvRV_2/2001 (JQ085407.1),

- RVA/chicken-wt/KOR/D62/2013 (KM254183.1),

- RVA/chicken-wt/DEU/Ch_03V0358F3/2003 (EU486975.1),

- RVF/chicken-wt/KOR/D62/2013 (KM254217.1),

- RVF/chicken-wt/DEU/0 3V0568/2003 (JQ919998.1),

- RVG/chicken/DEU/3V0567/2003 (JQ920007.1),

- RVG/Pigeon-wt/CHN/HK18/2011 (KC876015.1),

- RVG/chicken/ZAF/MRC_DPRU1679/2011/GXP[X] (KJ752089.1).

\section{Ethics}

The present study was authorized by the Brazilian Ministry of the Environment under approval number 21312-1 as well as the Chico Mendes Institute for Biodiversity Conservation (ICMBio) and Biodiversity Authorization and Information System (SISBIO). In addition, the study was approved by the Ethics Committee on the Use of Animals of Instituto Evandro Chagas (IEC) under registration number 014/2012.

\section{RESULTS}

\section{Detection and molecular characterization}

Twenty-three fecal samples of the species Calidris pusilla, Numenius phaeopusand and Charadrius semipalmatus with no clinical signs of diarrhea were tested by PAGE and RT-PCR to PBV, ARV, AvRVA (Avian Rotavirus A; VP6 and NSP4 genes) and AvRVD (Avian Rotavirus D; VP7 and VP6 genes). The electrophoretic profiles were not detected by PAGE, and the amplification for the studied viruses PBV, ARV, AvRVA and AvRVD (VP6 and NSP4 genes) were negative. Positivity for AvRVD, VP7 gene was of $4.35 \%(1 / 23)$ for the migratory bird Calidris pusilla.

Avian Rotavirus Group D identified in this study was phylogenetically related and grouped into one branch together to previously reported AvRVD from Brazil (KC669409, KC669410) with 95\% identity, India (KF142489) 81\% identity and South Korea (KM254196), 84\% identity, but all recovered from flock chicken (Figure 1).

The data show similarity with rotavirus $D$ in Brazil for the years 2008-2011, with 99.8\% nucleotide similarity and $100 \%$ amino acid similar to RVD/chicken-wt/ BRA/94/2010 (Table 1).

However, when compared with Brazilian prototypes, nucleotide and amino acid similarities were observed, respectively, in the years 2008 (96.03\% and $97.59 \%)$, 2009 (95.83\% and 96.39\%), 2010 (95.63\% and $97.59 \%)$ and 2011 (95.44\% and 96.39\%) as demonstrated in Table 1.

Table 1 - Analysis of nucleotide and amino acids similarity sample AvRVD/Sandpiper-wt/BRA/2011 compared with the other strains of rotavirus circulating $D$ in Brazil and the world.

\begin{tabular}{lcc}
\hline & $\begin{array}{c}\text { Nucleotide } \\
\text { Similarity }\end{array}$ & $\begin{array}{c}\text { Amino Acid } \\
\text { Similarity }\end{array}$ \\
\hline AvRVD/chicken-wt/BRA/94/2010 & $99.80 \%$ & $100.00 \%$ \\
AvRVD/chicken-wt/BRA/29/2008 & $96.03 \%$ & $97.59 \%$ \\
AvRVD/chicken-wt/BRA/37/PA/2009 & $95.83 \%$ & $96.39 \%$ \\
AvRVD/chicken-wt/BRA/105A/PA/2010 & $95.63 \%$ & $97.59 \%$ \\
AvRVD/chicken-wt/BRA/109/PA/2011 & $95.44 \%$ & $96.39 \%$ \\
AvRVD/chicken-wt/DEU/05V0049/2005 & $86.51 \%$ & $87.95 \%$ \\
AvRVD/chicken-wt/KOR/D62/2013 & $83.53 \%$ & $86.14 \%$ \\
AvRVD/chicken/IND/UKD48/2012 & $81.15 \%$ & $84.94 \%$ \\
\hline
\end{tabular}

\section{DISCUSSION}

To our knowledge, this is the first report of the detection of rotaviruses in migratory birds in America. AvRVD was detected in 2011 in one sample recovered from Calidris pusilla with no clinical signs of diarrhea 
Guerreiro AN, Moraes CCG, Marinho ANR, Barros BCV, Bezerra DAM, Bandeira RS, Silva RR, Rocha DCC, Meneses AMC, Luz MA, Paz GS, Mascarenhas JDP
Investigation of Enteric Viruses in the Feces of Neotropical Migratory Birds Captured on the Coast of the State of Pará, Brazil

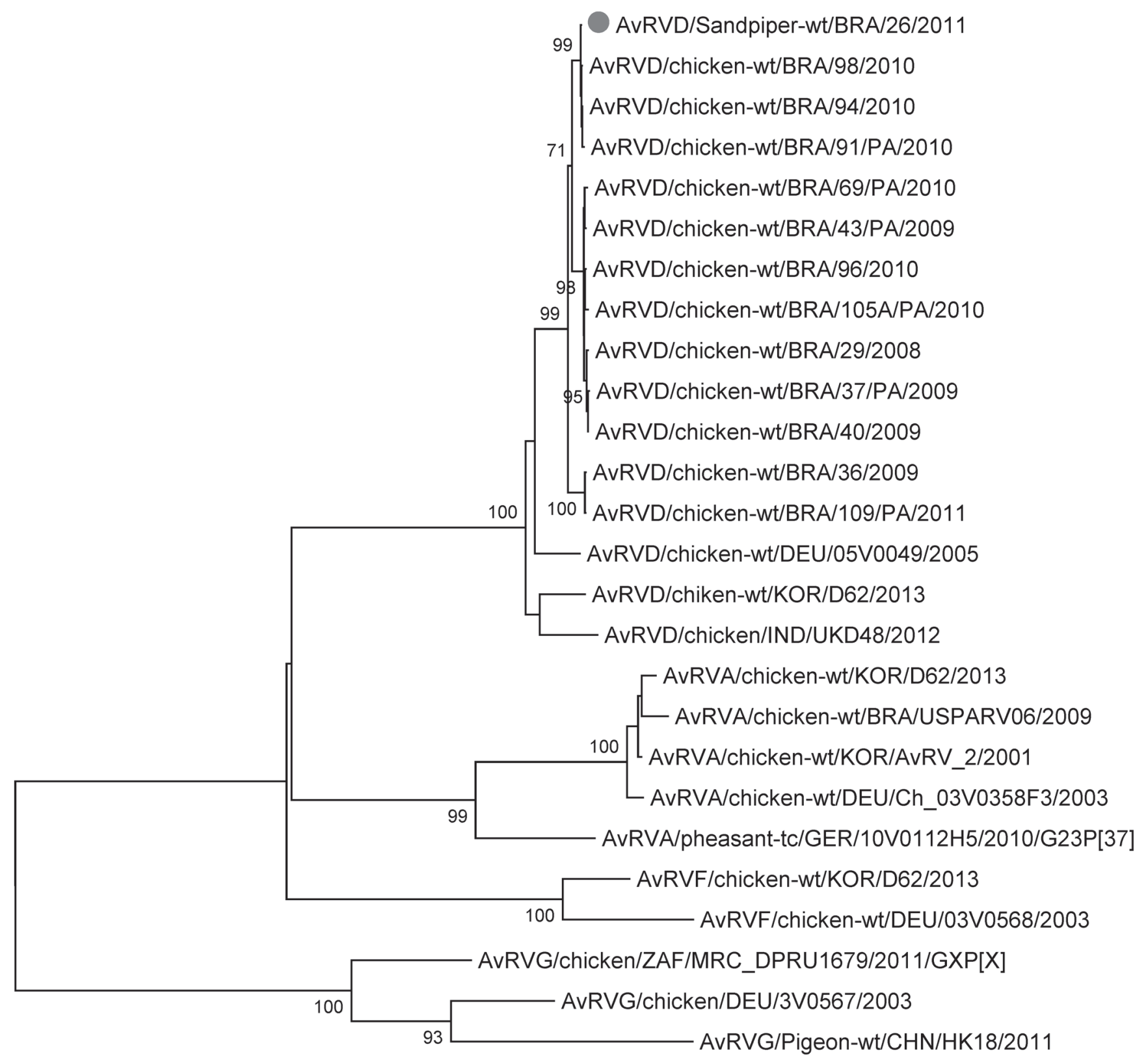

0.2

Figure 1 - The evolutionary history was inferred using the Neighbor-Joining method. The optimal tree with the sum of branch length $=0.84996118$ is shown. The percentage of replicate trees in which the associated taxa clustered together in the bootstrap test (2000 replicates) are shown next to the branches. The tree is drawn to scale, with branch lengths in the same units as those of the evolutionary distances used to infer the phylogenetic tree. The analysis involved 20 nucleotide sequences. Codon positions included were $1 s t+2 n d+3 r d+$ Noncoding. All positions containing gaps and missing data were eliminated. There was a total of 230 positions in the final dataset. Evolutionary analyses were conducted in MEGA6.

captured at Corvina Beach, Salinópolis Municipality, Pará State, Brazil. This result shows the occurrence of AvRVD in Neotropical migratory birds since there is no evidence of rotavirus in migratory birds worldwide.

Ecological associations have been carried out between bird's vectors for a wide range of microorganisms. In some cases, birds may be the main host of the virus (or even single), while in other cases; birds can be virus-amplifying hosts, necessary for the worsening of epizootic and other epidemic outbreaks. However, regarding wild birds this is the first report (Tsiodras et al., 2008; Dhama et al., 2015). Rotavirus can be identified both in symptomatic and asymptomatic animals. However, detection success increases when diarrheal samples are analyzed due to the possibility of higher viral load. In the present study, the appearance of the feces was observed, and none of the birds showed clinical signs of diarrhea, which may explain 
Guerreiro AN, Moraes CCG, Marinho ANR, Barros BCV, Bezerra DAM, Bandeira RS, Silva RR, Rocha DCC, Meneses AMC, Luz MA, Paz GS, Mascarenhas JDP
Investigation of Enteric Viruses in the Feces of Neotropical Migratory Birds Captured on the Coast of the State of Pará, Brazil the majority of negative results found. However, cases of AvRV detection in asymptomatic birds were found by Villarreal et al. (2006), who concluded that there were no significant differences in the detection of this agent in birds with or without the presence of clinical signs.

The frequency observed in the present study if compared with wild bird is very low. Similar results were found in India by Savita et al. (2008) and Islam et al. (2009) in fecal samples from farm broilers, which presented a positivity of $11.69 \%$ and $13.15 \%$, respectively. Ahmed \& Ahmed (2006) conducted a study on 232 fecal samples from broilers between 1 and 2 weeks of age from two districts of Bangladesh and observed $0.86 \%$ positivity for AvRV-A. In contrast, Karim et al. (2007) observed $13.81 \%$ positivity for AvRVD in 630 fecal samples from diarrheal and nondiarrheal stools of poultry at 3 weeks of age from four districts of Bangladesh. Similar results were found in India by Savita et al. (2008) and Islam et al. (2009) in fecal samples from farm broilers, which presented a positivity of $11.69 \%$ and $13.15 \%$, respectively.

Nunes et al. (2006) reported that wild and/or migratory birds are carriers of viral pathogens confirming our data that identify the presence of AvRVD. In birds, other viral pathogens were described such as astroviruses, enteroviruses, reoviruses, paramyxovirus and adenovirus, which can cause premature death of the specimens contaminated by other agents in conjunction with $A v R V_{L}$ making it impossible to identify the RV (Rotavirus) in migratory birds (Tamehiro et al., 2003; Nunes et al., 2006; Dhama et al., 2015).

It is important to mention that the birds in the present study were all adults, which may have hindered AvRV detection because it is known that young birds are more susceptible to infection due of slow replacement of the apical epithelium of the intestinal villi, which favors the full development of the AvRV replication cycle and the production of viral progeny (Alfieri et al., 2007). This situation does not occur in adult birds due to rapid replacement of the epithelium; thus, the formation of complete and infectious viral particles is hindered, which explains the AvRV detection in the studies by Ahmed \& Ahmed (2006), Karim et al. (2007) and Islam et al. (2009). The present study corroborates the study by Ursu et al. (2011), who correlated the low positivity found with the age range (adults) of the wild birds involved in their study, however, these authors detected AvRVA gene VP6.

The limited AvRV studies in Brazil include a study conducted by Tamehiro et al. (2003), who was able to detect $8.5 \%$ positivity for AvRV by PAGE in 378 fecal samples of 1-7-week-old farm broilers in the state of Paraná, Brazil. This result was different from that found by Villarreal et al. (2006), who observed $45.3 \%$ positivity for AvRVA by PAGE in 128 samples of broiler intestinal contents of animals from different states with rotavirus research in Brazil (Alfieri et al., 2007). Although there are no studies on the contact of farm animals and migratory birds, in our study it was observed that the strain identified in migratory birds is closely related to AvRVD circulating in Brazil in the same period, with similar nucleotide the AvRVD/ chickenwt/BRA/94/2010 of $99.8 \%$ and $100 \%$ amino acid, showing no change from amino acidic sites, whereas when compared with other samples described in other countries, a lower similarity is observed, suggesting that what was observed on migratory birds reflects the strain circulating in Brazil, indicating that crossinfection of domestic and migratory specimens may occur, but the mechanism of this cross-infection is not known.

Studies conducted on PBV report a wide range of hosts with the detection of these viruses in domestic and captive animals (Alfieri et al., 1988; Pereira et al., 1988; Fregolente et al., 2009). In this study, primers PicoB25 and PicoB43, the same used in the study by Silva et al. (2013) were employed, which developed RT-PCR to investigate 85 fecal sample pools from 37 poultry farms distributed among eight municipalities in the state of Pará, Brazil and found 49.4\% (42/85) positivity for this virus. However, in this study, no positive samples were obtained, which corroborates the absence of PBV in migratory birds in the literature.

One hypothesis that would explain the negative findings of the present study is that only primers that identify samples belonging to PBV genogroup I were used, thus underestimating the actual prevalence of picobirnaviruses among the migratory birds under, because genogroup II or non-I and non-II samples were not examined in the present study. Therefore, additional studies should be conducted to determine the evolutionary pattern of PBVs circulating among different geographical regions (Ganesh et al., 2011).

As for ARV, there are few studies focused on the molecular epidemiology of this agent in migratory birds, particularly for the S2 gene. However, results that diverged from those found in the present study were observed by Lojkic et al. (2010), who identified $13 \%$ positivity for ARV in fecal samples from turkeys in Croatia using the same primers as in the present study. In Brazil, Silva et al. (2013) used the same primers as in the present study and observed a prevalence of $32.9 \%$ (28/85) for ARV by RT-PCR of 85 fecal samples from 37 poultry farms. 
Guerreiro AN, Moraes CCG,

Marinho ANR, Barros BCV, Bezerra DAM,

Bandeira RS, Silva RR, Rocha DCC,

Meneses AMC, Luz MA, Paz GS,

Mascarenhas JDP
Investigation of Enteric Viruses in the Feces of Neotropical Migratory Birds Captured on the Coast of the State of Pará, Brazil
In summary, all fecal samples from neotropical migratory birds were negative for PBV, ARV and AvRVA and only AvRVD was detected in Calidris pusilla as the only pathogen in these neotropical migratory birds. Nevertheless, it is valid to correlate the importance of the finding in the context of the Brazilian poultry industry, that is configured as an important segment of agribusiness exploring the probable risks of migratory birds as enteric virus reservoir for commercial poultry or vice versa due to previous detections of AvRVD (Avian Rotavirus D), AvRVA (Avian Rotavirus A), AvRVF (Avian Rotavirus F) and AvRVG (Avian Rotavirus G) in broilers in Brazilian territory (Bezerra et al., 2012; Luz et al., 2014; Silva et al., 2013; Mascarenhas et al., 2016).

This result is relevant for the monitoring of migratory birds and highlights the importance of further studies aiming to clarify the actual role of these birds in the epidemiology of rotavirus in the Americas.

\section{ACKNOWLEDGEMENTS}

We appreciate the support of the Dean of Research and Studies Graduation (PROPESP) and the Foundation for Research Support and Development (FADESP) for grant no.01/2014 Program for Supporting the Qualified Research (PAPQ). We also thank the Laboratory of Rotavirus at the Institute Evandro Chagas (IEC / PA) for the opportunity of conducting the laboratory analysis team and the Laboratory of Ornithology of the Emilio Goeldi Museum (MPEG) staff for the help in collecting and capturing migratory birds, and the National Council for Scientific and Technological Development (CNPq) for granting the scholarship. J.D.P. Mascarenhas is the recipient of CNPq fellowship.

\section{REFERENCES}

Ahmed MS, Ahmed MU. Detection of avian rotavirus-like virus in broiler chickens in Bangladesh. Bangladesh Journal Veterinary Medicine 2006;4(2):73-77.

Alfieri AF, Alfieri AA, Resende JS, Resende M. A new bisegmented double stranded RNA virus in avian faeces. Arquivo Brasileiro de Medicina Veterinária e Zootecnia 1988;40:437-440.

Alfieri AF, Alfieri AA, Resende JS, Resende M. Atypical rotavirus infections among broiler chickens in Brazil. Arquivo Brasileiro de Medicina Veterinária e Zootecnia 1989;41:81-82.

Alfieri AA, Alfieri AF, Takiuchi E, Lobato ZIP. Reoviridae. In: Flores EF, editor. Virologia veterinária. Santa Maria: Universidade Federal de Santa Maria; 2007. 780p.

Bengis RG, Leighton FA, Fischer JR, Artois M, Mörner T, Tate CM. The role of wildlife in emerging and re-emerging zoonoses. Revue Scientifique et Technique 2004;23:497-511.
Bergeland ME, McAdaragh JP, Stotz I. Enterite por rotavirus em perus. Proceedings of the $26^{\text {th }}$ Western Poultry Diseases Conference; 1997; Davis. California: University of California; 1977. p.29-120.

Bezerra DAM, Silva RR, Kaiano JHL, Silvestre RVD, Oliveira DS, Linhares AC, et al. Detection of avian group $D$ rotavirus using the polymerase chain reaction for the VP6 gene. Journal Virological Methods 2012;185:189192.

Boom R, Sol CJA, Salimans MMM, Jansen CL, Wertheim-Van Dillen PME, et al. Rapid and simple method for purifications of nucleic acids. Journal Clinical Microbiology 1990;28(3):495-503.

Dos Santos HF, Lovato LT, Flôres ML, Trevisoli IMK, Mazzutti C, Pan KA. Anticorpos contra vírus em galinhas de terreiro do estado do Rio Grande do Sul, Brasil. Ciência Rural 2008;38(7):1932-1937.

Dhama K, Saminathan M, Karthik K, Tiwari R, Shabbir MZ, Kumar N, et al. Avian rotavirus enteritis - an updated review. Veterinary Quarterly 2015:8:39-84

Estes MK, Greenberg HB. Rotavirus. In: Knipe DM, Howley PM, editors. Fields virology. $6^{\text {th }}$ ed. Philadelphia: Lippincott Williams \& Wilkins; 2013. p.1347-1401.

Fregolente MCD, Castro-Dias E, Martins SS, Spilki FR, Allegretti SM, Gatti MSV. Molecular characterization of picobirnaviruses from new hosts. Virus Research 2009;143(1):134-136.

Ganesh B, Nagashima S, Ghosh S, Nataraju SM, Rajendran K, Manna B, et al. Detection and molecular characterization of multiple strains of picobirnavirus causing mixed infection in a diarrhoeic child: Emergence of prototype Genogroup II-like strain in Kolkata, India. International Journal of Molecular Epidemiology and Genetics 2011;2(1):61-72.

Goldenberg D, Pasmanik-Chorc M, Pirakd M, Kassd N, Lubline A, Yeheskelc $A$, et al. Genetic and antigenic characterization of sigma $C$ protein from avian reovirus. Avian Pathology 2010;39(3):189-199.

Hall TA. BioEdit: a user-friendly biological sequence alignment editor and analysis program for Windows 95/98/NT. Nucleic Acids Symposium Series 1999;41:95-98.

Islam M.S, Alam MM, Ahmed MU, Saifuzzaman ABM, Kobayashi N, Kayesh $\mathrm{MEH}$, et al. Molecular epidemiologic study on rotavirus infection in human and birds in association with gastroenteritis. Bangladesh Journal of Veterinary Medicine 2009;7:233-237.

Johne R, Otto P, Roth B, Löhren U, Belnap D, Reetz J, et al. Sequence analysis of the VP6-encoding genome segment of avian group $F$ and $G$ rotaviruses. Virology 2011;442:384-439.

Karim MR, Rume Fl, Alam MM, Ahmed MU. Molecular epidemiologic study on avian rotavirus prevailing in Bangladesh. Bangladesh Journal of Veterinary Medicine 2007;5(1/2):43-48.

Kimura M. A simple method for estimating evolutionary rate of base substitution through comparative studies of nucleotide sequences. Journal of Molecular Evolution 1980;16:111-120.

Lojkić I, Bidin M, Bidin Z, Mikec M. Viral agents associated with poultry enteritis in Croatian commercial turkey flocks. Acta Veterinaria Brno 2010;79:91-98.

Luz MA, Bezerra DAM, Silva RR, Guerreiro AN, Seixas LS, Basto RKG, et al. Pesquisa de rotavírus em aves silvestres da região amazônica mantidas em cativeiro no estado do Pará. Revista Brasileira de Medicina Veterinária 2014;2(36):167-173.

Malik YS, Kumar N, Dhama K, Banyai K, Mascarenhas JDP, Singh RK Picobirnaviruses. In: Dongyou L, organizer. Molecular detection of animal viral pathogens. Boca Raton: CRC Press Taylor \& Francis Group; 2016. p.585-592. 
Guerreiro AN, Moraes CCG,

Marinho ANR, Barros BCV, Bezerra DAM,

Bandeira RS, Silva RR, Rocha DCC,

Meneses AMC, Luz MA, Paz GS,

Mascarenhas JDP

Mascarenhas JD, Bezerra DA, Silva RR, Silva MJ, Júnior EC, Soares LS. Detection of the VP6 gene of group $F$ and $G$ rotaviruses in broiler chicken fecal samples from the Amazon region of Brazil. Archives of Virology 2016;161:2263-2268.

Matthijnssens J, Otto PH, Ciarlet M, Desselberger U, Van Ranst M, Johne R. VP6-sequence-based cutoff values as a criterion for rotavirus species demarcation. Archives of Virology 2012;157:1177-1182.

Mihalov-Kovács E, Gellért Á, Marton S, Farkas SL, Fehér E, Oldal M, et al. Candidate new rotavirus species in sheltered dogs, Hungary. Emerging Infectious Diseases 2015;21:660-663.

Nunes MFC, Lacerda R, Roos A, Costa J. Aves migratórias na Amazônia e a gripe aviária. [Informação CEMAVE, 35 /2006]. Cabedelo: Centro Nacional de Pesquisa para Conservação das Aves Silvestres; 2006.

Otto PH, Ahmed MU, Hotzel H, Machnowska P, Reetz J, Roth B, et al. Detection of avian rotaviruses of groups $A, D, F$ and $G$ in diseased chickens and turkeys from Europe and Bangladesh. Veterinary Microbiology 2012;156:8-15.

Pereira HG, Flewett TH, Candeias JAN, Barth OM. A virus with a bisegmented double-stranded RNA genome in rat (Oryzomysnigripes) intestines. Journal of General Virology 1988;69(11):397-398.

Pereira HG, Linhares AC, Candeias JAN, Glass RI. National laboratory surveillance of viral agents of gastroenteritis in Brazil. Bulletin of the Pan American Health Organization 1993;27(3):224-233.

Rosen BI, Fang ZY, Glass RI, Monroe SS. Cloning of human picobirnavirus genomic segments and development of an RT-PCR detection assay. Virology 2000;277(2):316-329.

Savita KAL, Kusumakar AL, Malik YPS, Minaksh PG, Prasad G. Detection and characterization of group $A$ and $D$ avian rotaviruses in India. Indian Journal of Biotechnology 2008;7:554-556.

\section{Investigation of Enteric Viruses in the Feces of Neotropical Migratory Birds Captured on the Coast of the State of Pará, Brazil}

Silva RR, Bezerra DAM, Kaiano JHL, Manno MC, Oliveira DS, Sagica FES et al. Molecular epidemiology of avian rotavirus in fecal samples of broiler chickens in Amazon Region, Brazil, from August 2008 to May 2011. Revista Pan-Amazônica de Saúde 2013;4(2):55-62.

Tamehiro CY, Alfieri AF, Medici C, Alfieri AA. Segmented double-stranded genomic RNA viruses in fecal samples from broiler chicken. Brazilian Journal of Microbiology 2003;34(4):344-348.

Tamura K, Stecher G, Peterson D, Filipski A, Kumar S. MEGA6: Molecular Evolutionary Genetics Analysis version 6.0. Molecular Biology and Evolution 2013;302:2725-2729.

Trojnar E, Otto P, Johne R. The first complete genome sequence of a chicken group A rotavirus indicates independent evolution of mammalian and avian strains. Virology 2009;386:325-333.

Tsiodras S, Kelesidis T, Kelesidis I, Bauchinger U, Falagas ME. Human infections associated with wild birds. Journal of Infection 2008;56:8398.

Ursu K, Papp H, Kisfali P, Rigó D, Melegh B, Martella V, et al. Monitoring of Group A Rotaviruses in Wild-Living Birds in Hungary. Avian Diseases 2011;55(1):123-127

Villarreal LYB, Uliana G, Valenzuela C, Chacón JLV, Saidenberg ABS, Sanches $A A$, et al. Rotavirus detection and isolation from chickens with or without symptoms. Brazilian Journal of Poultry Science 2006;8(3):187191.

Zhang Y, Liu M, Shuidong O, Hu QL, Guo DC, Chen HY, et al. Detection and identification of avian, duck, and goose reoviruses by RT-PCR: goose and duck reoviroses are part of the same genogroup in the genus Orthoreovirus. Archives of Virology 2006;151:1525-1538. 